\title{
Trastuzumab Biosimilar is Coming
}

\author{
Yunseon Choi* \\ Department of Radiation Oncology, Busan Paik Hospital, Inje University School of Medicine, Korea
}

Submission: June 01, 2017; Published: June 22, 2017

*Corresponding author: Yunseon Choi, Department of Radiation Oncology, Busan Paik Hospital, Inje University School of Medicine, Bokjiro 75, Busanjin-gu, Busan, 47392, Republic of Korea, Tel: +82-51-890-8606; Fax: +82-51-891-1754; Email: rtyoon@gmail.com

\section{Opinion}

Over the past decade, treatment outcomes for human epidermal growth factor receptor 2 (HER2)-positive breast cancer have significantly improved because of the use of trastuzumab. Trastuzumab, a recombinant DNA-derived humanized monoclonal antibody, was approved by the Food and Drug Administration (FDA) in 1998 and is now used worldwide. Trastuzumab, the second monoclonal antibody in the world to be approved, has resulted in a better prognosis for HER2-positive breast cancer and improved survival rates. Trastuzumab is indicated mainly in HER2-positive advanced breast cancer [1], metastatic breast cancer [2], and gastric cancer [3].

The global market size of trastuzumab was recently estimated to be approximately $\$ 6.5$ billion. However, Herceptin, the first manufactured trastuzumab by Genentec and Roche, still tends to be expensive. Therefore, there is great demand for affordable drugs that can be used by more patients around the world and that have expanded coverage. A biosimilar is defined as a type of biological product that is approved by the FDA because of its high clinical similarity to an already FDA-approved biological product. Patents of Herceptin finally expired in Asia in 2017, and trastuzumab biosimilars will eventually be released on to the market later this year. This biosimilar sale is expected to begin in Europe this year, where patent rights are extinguished, and spread to the North American market. The FDA is reviewing the approval of these biosimilars, and many will be distributed to the market next year, when North American patents expire.

Recently, several companies have been preparing for the release of trastuzumab biosimilars [4,5]. First, the Biocon and Mylan collaboration reported their results of a global clinical trial last year [4], and are in the process of preparing for the launch in the US, in agreement with Roche. Amgen, Celltrion, and Samsung Biologics are also in the process of launching trastuzumab biosimilars in the market. Among them, Celltrion is expected to start selling trastuzumab biosimilars in Europe after Asia later this year.

The prices of trastuzumab biosimilars are predicted to be $80 \%$ of that of Herceptin. The demand for Trastuzumab is expected to increase in developing countries if prices are lowered. In addition, low-income patients will be able to use enough trastuzumab for one year. For advanced gastric cancer, trastuzumab will be used in approximately $15 \%$ of HER2positive patients. It is expected that trastuzumab biosimilars will be used even more through precision medicine and personalized treatments based on genetic analysis. There is also a possibility that trastuzumab biosimilars will be used on a trial basis to treat HER2-positive cancers that have not been previously treated with trastuzumab.

Products that enhance trastuzumab's capabilities are also being released in the market. This can be seen as Roche's defense strategy. The new type of Herceptin, which can be subcutaneously injected, has already received a good response on the market. T-DM1 (ado-trastuzumab emtansine, Kadcyla), an antibodychemotherapeutic drug conjugate, showed similar therapeutic effects as the combination of trastuzumab and chemotherapy with taxane [6]. By targeting other parts of the ErbB receptor, pertuzumab (Perjeta), released by Roche, is able to act in a complementary manner and provides more complete blockade of HER2-driven signaling when combined with trastuzumab [7]. Therefore, in addition to trastuzumab biosimilars, it seems that more bio betters, which enhance efficacy or reduce cardiac toxicity [8], will be released in a few years.

The development of targeted anticancer therapies using recombinant antibodies has opened a new era in cancer treatment. Now, with the introduction of biosimilars, price cuts will make them more accessible and more widely used. This will be a new opportunity for manufacturers and a change welcomed by many patients.

\section{References}

1. Romond EH, Perez EA, Bryant J, Suman VJ, Geyer CEJ, et al. (2005) Trastuzumab plus Adjuvant Chemotherapy for Operable HER2-Positive Breast Cancer. N Engl J Med 353(16): 1673-1684.

2. Vogel CL, Cobleigh MA, Tripathy D, Gutheil JC, Harris LN, et al. (2002) Efficacy and safety of trastuzumab as a single agent in first-line treatment of HER2-overexpressing metastatic breast cancer. J Clin Oncol 20(3): 719-726. 
3. Bang YJ, Van Cutsem E, Feyereislova A, Chung HC, Shen L, et al (2010) Trastuzumab in combination with chemotherapy versus chemotherapy alone for treatment of HER2-positive advanced gastric or gastro-oesophageal junction cancer (ToGA): a phase 3, open-label, randomised controlled trial. Lancet 376(9742): 687-697.

4. Rugo HS, Barve A, Waller CF, Hernandez-Bronchud M, Herson J, et al. (2017) Effect of a Proposed Trastuzumab Biosimilar Compared With Trastuzumab on Overall Response Rate in Patients With ERBB2 (HER2)-Positive Metastatic Breast Cancer: A Randomized Clinical Trial. JAMA 317(1): 37-47.

5. Morita J, Tanaka M, Nomoto M, Matsuki S, Tsuru T, et al. (2016) Pharmacokinetic Bioequivalence, Safety, and Immunogenicity of DMB3111, a Trastuzumab Biosimilar, and Trastuzumab in Healthy Japanese Adult Males: Results of a Randomized Trial. BioDrugs 30(1): 17-25.

This work is licensed under Creative Commons Attribution 4.0 Licens

DOI: 10.19080/JTMP.2017.01.555560
6. Perez EA, Barrios C, Eiermann W, Toi M, Im YH, et al. (2017) Trastuzumab Emtansine with or without Pertuzumab Versus Trastuzumab Plus Taxane for Human Epidermal Growth Factor Receptor 2-Positive, Advanced Breast Cancer: Primary Results From the Phase III MARIANNE Study. J Clin Oncol 35(2): 141-148.

7. Beitsch P, Whitworth P, Baron P, Rotkis MC, Mislowsky AM, et al. (2017) Pertuzumab/Trastuzumab/CT Versus Trastuzumab/CT Therapy for HER2+ Breast Cancer: Results from the Prospective Neoadjuvant Breast Registry Symphony Trial (NBRST). Ann Surg Oncol.

8. Wittayanukorn S, Qian J, Westrick SC, Billor N, Johnson B, et al. (2017) Prevention of Trastuzumab and Anthracycline-induced Cardiotoxicity Using Angiotensin-converting Enzyme Inhibitors or beta-blockers in Older Adults With Breast Cancer. Am J Clin Oncol.

\section{Your next submission with Juniper Publishers will reach you the below assets}

- Quality Editorial service

- Swift Peer Review

- Reprints availability

- E-prints Service

- Manuscript Podcast for convenient understanding

- Global attainment for your research

- Manuscript accessibility in different formats

( Pdf, E-pub, Full Text, Audio)

- Unceasing customer service

Track the below URL for one-step submission https://juniperpublishers.com/online-submission.php 